University of Nebraska - Lincoln

DigitalCommons@University of Nebraska - Lincoln

1998

\title{
Effects of Extruded Corn or Grain Sorghum on Intake, Digestibility, Weight Gain, and Carcasses of Finishing Steers
}

\author{
R. J. Gaebe \\ University of Wyoming \\ D. W. Sanson \\ University of Wyoming \\ Ivan G. Rush \\ University of Nebraska-Lincoln, irush1@unl.edu \\ M. L. Riley \\ University of Wyoming \\ D. L. Hixon \\ University of Wyoming, dhixon@uwyo.edu \\ See next page for additional authors
}

Follow this and additional works at: https://digitalcommons.unl.edu/panhandleresext

Part of the Agriculture Commons

Gaebe, R. J.; Sanson, D. W.; Rush, Ivan G.; Riley, M. L.; Hixon, D. L.; and Paisley, S. I., "Effects of Extruded Corn or Grain Sorghum on Intake, Digestibility, Weight Gain, and Carcasses of Finishing Steers" (1998). Panhandle Research and Extension Center. 23.

https://digitalcommons.unl.edu/panhandleresext/23

This Article is brought to you for free and open access by the Agricultural Research Division of IANR at DigitalCommons@University of Nebraska - Lincoln. It has been accepted for inclusion in Panhandle Research and Extension Center by an authorized administrator of DigitalCommons@University of Nebraska - Lincoln. 


\section{Authors}

R. J. Gaebe, D. W. Sanson, Ivan G. Rush, M. L. Riley, D. L. Hixon, and S. I. Paisley 


\title{
Effects of Extruded Corn or Grain Sorghum on Intake, Digestibility, Weight Gain, and Carcasses of Finishing Steers ${ }^{1}$
}

\author{
R. J. Gaebe*,2, D. W. Sanson*,3, I. G. Rusht, M. L. Riley*, \\ D. L. Hixon*, and S. I. Paisley*,4
}

*Department of Animal Science, University of Wyoming, Laramie 82071-3684 and
†Panhandle Research and Extension Center, University of Nebraska, Scottsbluff 69361

ABSTRACT: We conducted two trials to evaluate the effects of extruding vs dry-rolling either corn or grain sorghum on intake, digestibility, and performance of finishing steers. In Trial 1, 92 crossbred steers (average BW $413 \mathrm{~kg}$ ) were used in a $2 \times 2$ factorial design. Diets contained either dry-rolled corn $(R C)$, extruded corn (EC), dry-rolled grain sorghum (RGS), or extruded grain sorghum (E GS). Diets were fed for $110 \mathrm{~d}$ and contained $78.6 \%$ of the respective grain, $9 \%$ alfalfa pellets, $8.2 \%$ molasses, and $4.2 \%$ protein-mineral supplement. Daily gain was highest ( $P<.049$ ) for steers fed RC, and the ADG of steers fed RGS was higher than that of steers fed extruded diets; there was no difference in ADG between steers fed EC and those fed EGS. Steers fed dry-rolled diets consumed more DM $(P=.001)$ than steers fed extruded diets. Feed efficiency was not affected ( $P=$ .18) by processing method, but steers fed corn utilized the diets more efficiently $(P=.006)$ than steers fed grain sorghum. Except for carcass weight, carcass data were not affected by grain type $(P>.20)$.
Dressing percentage, quality grade, and longissimus muscle area were lower $(P<.09)$ in steers that received extruded grain than in those that received dry-rolled grain. In Trial 2, five ruminally cannulated crossbred steers (average BW $518 \mathrm{~kg}$ ) were used in a $4 \times 4+1$ Latin square design to evaluate the ruminal and total tract digestion characteristics of the diets used in Trial 1. Type of grain had no effect $(P>.16)$ on intake, total tract digestibility, or ruminal $\mathrm{pH}$. Extruding corn or grain sorghum decreased intake ( $P$ $<.001)$ but increased $(P<.074) D M$ and starch digestibility compared with dry rolling; steers fed extruded diets had lower $(P<.032)$ ADF and NDF digestibilities. Ruminal in situ DM and starch disappearance were higher $(P<.03)$ and ruminal $\mathrm{pH}$ was lower $(P<.052)$ in steers fed extruded grains than in those fed dry-rolled grains. Data from this study indicate that extruded corn and extruded grain sorghum are highly degradable feeds; however, decreased DM intake and lower ruminal pH levels resulted in lower performance.

Key Words: Intake, Digestibility, Performance, Processing, Cattle

(01998 American Society of Animal Science All rights reserved.

J. Anim. Sci. 1998. 76:2001-2007

\section{Introduction}

Most cereal grain-processing methods have as their primary objective to improve starch availability, which results in enhanced digestion and feed efficiency. With

\footnotetext{
${ }^{1}$ Appreciation is expressed to Elanco Animal Health, Indianapolis, IN, for providing the rumensin (monensin sodium) and tylosin; Merck AgVet, Rahway, NJ , for providing the Ivomectin; and Fort Dodge Animal Health, Inc., F ort Dodge, IA, for providing the growth implants (Synovex-S).

${ }^{2}$ Current address: P.O. Box 252, Napoleon, ND 58561.

3To whom correspondence should be addressed: Rosepine Research Station, P.O. Box 387, Rosepine, LA 70659.

${ }^{4}$ Current address: Animal Science Dept., Oklahoma State Univ., Stillwater 74078-0425.

Received J uly 14, 1997.

Accepted March 17, 1998.
}

feedlot diets, grain processing may improve feed efficiency 3 to $5 \%$ for corn and 8 to $15 \%$ for grain sorghum; however, rate of gain may be negatively affected (Guyer, 1976; Huntington, 1997). Grinding, crushing, and rolling seemed to improve palatability and(or) utilization of certain grains (Hale, 1973). Other processing methods involving the addition of heat and(or) water, such as steam-flaking, popping, and micronizing, have improved the feed utilization of certain grains compared with grinding or rolling (E II is and Carpenter, 1966; J ohnson et al., 1968, Theurer et al., 1996). In general, most methods of processing cereal grain improve utilization by improving starch availability.

Certain processing methods disrupt the protein matrix of the endosperm and thus permit easier enzymatic access to the starch granules (Rooney and Pflugfelder, 1986). Theurer (1986) reported that total 
starch digestibility averaged $98 \%$ for grain sorghum processed by steam-flaking, micronizing, or reconstitution, compared with $91 \%$ for grain sorghum processed by dry rolling or grinding. Extrusion allows starch gelatinization to occur at low moisture levels (Harper, 1981), which results in increased ruminal starch degradation (Walhain et al., 1992); however, researchers using extruded corn diets have reported varied results (Matsushima et al., 1969; Matsushima, 1970; MCLaren and Matsushima, 1971) in the performance of feedlot cattle.

The objective of this experiment was to compare the effects of extruding vs dry-rolling corn or grain sorghum on the performance and carcass characteristics of feedlot cattle and on ruminal and total tract digestion characteristics of cannulated steers.

\section{Materials and Methods}

Trial 1. Ninety-two crossbred steers with an average initial weight of $413 \mathrm{~kg}$ were used in a 110-d feedlot trial to measure the effects of extruding vs dry-rolling of corn or grain sorghum in finishing diets using a 2 (grain type) $\times 2$ (processing method) factorial arrangement of treatments. The four treatments were dry-rolled corn, extruded corn, dry-rolled grain sorghum, and extruded grain sorghum. Steers were stratified by weight into four weight groups and within each weight group were randomly allotted to one of the four treatments. This resulted in six steers per pen in replicates one through three and five steers per pen in replicate four.

Grains used in all four diets were initially processed with a roller mill so that kernels were cracked into two to three pieces. Subsequently, corn and grain sorghum used in the extruded diets were processed using an Insta-Pro 2000R (Insta-Pro, Des Moines, I A) extruder. Temperatures reached approximately $280^{\circ} \mathrm{F}$ during the extruding process. Water was added to the

Table 1. Diet formulations and chemical composition of diets fed to steers in Trials 1 and 2

\begin{tabular}{lrrrrr}
\hline \hline & \multicolumn{2}{c}{ Corn } & & \multicolumn{2}{c}{ Grain sorghum } \\
\cline { 2 - 3 } \cline { 6 - 6 } Item & $\begin{array}{c}\text { Dry- } \\
\text { rolled }\end{array}$ & Extruded & & $\begin{array}{c}\text { Dry- } \\
\text { rolled }\end{array}$ & Extruded \\
\hline Grain, \% & 78.6 & 78.6 & & 78.6 & 78.6 \\
Dehydrated alfalfa, \% & 9.0 & 9.0 & & 9.0 & 9.0 \\
Molasses, \% & 8.2 & 8.2 & & 8.2 & 8.2 \\
Protein supplement, \% & 4.2 & 4.2 & & 4.2 & 4.2 \\
Chemical composition, \% & & & & & \\
DM & 85.3 & 87.6 & & 86.3 & 87.8 \\
Ash & 5.0 & 4.9 & & 5.4 & 5.7 \\
Crude protein & 11.9 & 12.7 & & 12.2 & 12.8 \\
NDF & 19.7 & 17.2 & & 21.3 & 18.6 \\
ADF & 9.2 & 8.9 & & 11.4 & 9.7 \\
Starch & 60.9 & 63.6 & & 64.9 & 61.9 \\
\hline
\end{tabular}

Table 2. Formulation of supplements for grain sorghum and corn diets in Trials 1 and 2

\begin{tabular}{lcc}
\hline \hline Ingredient, \% & Corn & Grain sorghum \\
\hline Grain sorghum & - & 30.6 \\
Corn & 22.6 & - \\
Limestone & 22.0 & 22.0 \\
Soybean meal & 20.0 & 20.0 \\
Urea & 20.4 & 12.4 \\
Molasses & 4.4 & 4.4 \\
Salt & 3.8 & 3.8 \\
Dicalcium P & 3.2 & 3.2 \\
KCl $_{\text {Trace mineral }}{ }^{\mathrm{a}}$ & 2.5 & 2.5 \\
Rumensin & .5 & .5 \\
Tylosin $^{\mathrm{b}}$ & .4 & .4 \\
\hline
\end{tabular}

aTrace mineral package contained $\geq 17.3 \% \mathrm{Zn}, \geq 14.8 \% \mathrm{Mn}, \geq 5.4 \%$ $\mathrm{Fe}, \geq 4.0 \% \mathrm{Cu}, \geq .3 \% \mathrm{I}$, and $\geq 0.9 \% \mathrm{Co}$.

${ }^{b}$ Rumensin (monensin sodium) and tylosin were provided by Elanco Animal Health (Indianapolis, IN).

grain through an injector on the extruder to keep grain flowing and to improve texture. Grains used in the extruded diets were not finely ground before extrusion.

Steers were housed in $29.3-\times 4.2-\mathrm{m}$ pens with automatic waterers and fence-line concrete feedbunks located under an open-faced metal shed. Four step-up diets were fed during the first $26 \mathrm{~d}$ of the feeding trial; Step 1 diets contained $43.75 \%$ grain. The level of grain was increased in each subsequent diet by $8.75 \%$ until the final diet concentration of $78.6 \%$ was reached (Table 1). All pens were switched to the next diet simultaneously. Diets were prepared twice weekly and stored in plywood boxes located in front of each pen. Protein supplements were formulated for corn and grain sorghum diets to provide equal amount of crude protein for all diets (Table 2). Feed was offered at 0700 each morning at levels to ensure a small amount of refusal. Refusals were removed from the bunks weekly and weighed. Diet DM was determined weekly from feed and refusal samples.

At the start of the trial, steers were weighed on two consecutive days, given a growth-promoting implant (200 mg of progesterone and $20 \mathrm{mg}$ of estradiol benzoate; Synovex- ${ }^{\circledR}$; Fort Dodge Animal Health, Fort Dodge, IA), vaccinated against respiratory and clostridial diseases, and dewormed with Ivomectin ${ }^{\circledR}$ (Merck AgVet, Rahway, NJ ). Upon completion of the 110-d feeding trial, steers were again weighed on two consecutive days before shipping for slaughter. Carcass data, including dressing percentage, marbling score, quality grade, fat thickness, longissimus muscle area, and yield grade, were collected at slaughter.

Trial 2. Five ruminally cannulated Angus-Gelbvieh crossbred steers (average BW $518 \mathrm{~kg}$ ) were used in a $4 \times 4+1$ Latin square design to evaluate intake, total tract digestion, and ruminal in situ disappearance of diets fed in Trial 1. Feed sources and diet formulations 
were the same as in Trial 1 (Tables 1 and 2). Steers were housed in an enclosed barn with controlled temperature in separate $3.6-\times 3.6-\mathrm{m}$ pens with free access to water. Steers were allowed free access to experimental diets; feed was weighed and offered once daily at 0700. Refused feed was weighed daily immediately before fresh feed was offered.

Each of four periods were $24 \mathrm{~d}$ in duration, which comprised $14 \mathrm{~d}$ for diet adaptation, followed by a 10-d sample-collection period. Ruminal fluid $\mathrm{pH}$ was measured on $d 15$ at $h-1$ and at $1,3,5,7,9,11,13$, 15,17 , and $23 \mathrm{~h}$ after feeding. In situ DM disappearance was determined using $30-\times 30-\mathrm{cm}$ Dacron ${ }^{\circledR}$ bags. Bags containing $20 \mathrm{~g}$ of the treatment grain were placed in the rumen at 0600 on $d 15$ and were removed after $0,2,4,6,8,12,16,24,36,48$, and $72 \mathrm{~h}$ of incubation. Grain used in the Dacron bag procedure was processed with the same methods used for feed treatments and was placed in bags in that form rather than being further processed. Upon removal from the rumen, bags were squeezed by hand to remove excess moisture and then frozen at $-20^{\circ} \mathrm{C}$ until the end of the collection. At that time, bags were thawed and rinsed with warm tap water until the rinse water was clear, squeezed by hand to remove excess water, and dried in a forced-air oven at $48^{\circ} \mathrm{C}$ for $96 \mathrm{~h}$.

Total fecal output was determined by collecting feces with fecal bags on d 19 through 24. Harnesses and fecal bags were placed on steers at 1800 on d 18 . Bags were changed at 0600 on $d 19$ and at 8-h intervals through d 24. Upon removal, individual bags containing feces were weighed, and the empty weight of the bag was subtracted to determine feces weight. Feces were mixed, and a $10 \%$ aliquot was stored at $2^{\circ} \mathrm{C}$ until the end of the period. Feed, refusal, and fecal samples were collected daily during the collection periods. Feed samples were composited into one sample per period. Fecal and refusal samples were composited within animal treatment for each period. Feed, feces, and refusal samples were dried with forced air at $48^{\circ} \mathrm{C}$ for $48 \mathrm{~h}$. A representative subsample of each was also dried at $100^{\circ} \mathrm{C}$ for $72 \mathrm{~h}$ to determine absolute DM. Samples dried at $48^{\circ} \mathrm{C}$ were allowed to air-equilibrate at room temperature for 48 $\mathrm{h}$, ground through a Wiley mill (2-mm screen), and stored in air-tight containers until analysis. Procedures for handling and care of animals were approved by the University of Wyoming Animal Care Committee and the committee's veterinarian.

Sample Analysis. Feed, refusal, and fecal samples were analyzed using procedures outlined by AOAC (1980) to determine DM, ash, and CP (Kjeldahl N × 6.25). Samples were analyzed for $C P$ using a microKjeldahl (Perstorp Analytical, Silver Spring, MD) procedure. Samples were analyzed for gross energy using an adiabatic oxygen bomb calorimeter (Parr Instrument, Moline, IL). All samples were analyzed for NDF and ADF using procedures described by
Goering and Van Soest (1970), except that Whatman 541 hardened ashless filter paper (Whatman, Hillsboro, OR) was used in place of fritted disk crucibles. Samples were incubated in a solution containing 15 $\mathrm{mL}$ of phosphate buffer and $.5 \mathrm{~mL}$ of bacterial $\alpha$ amylase for 12 to $18 \mathrm{~h}$ (McQueen and Nicholson, 1979) before NDF analysis. Starch analysis was performed using the procedure outlined by McRae and Armstrong (1968) with modifications suggested by Matejovsky and Sanson (1995). Starch analysis was also conducted on Dacron bag residue.

Statistical Analysis. In Trial 1, initial and final weights, weight gain, ADG, DM intake, feed efficiency, carcass weight, dressing percentage, marbling score, quality grade, fat thickness, longissimus muscle area, and yield grade were analyzed using a $2 \times 2$ factorial treatment analysis (SAS, 1989). Pen was used as the experimental unit. When a grain type $\times$ processing method interaction was observed, data were reanalyzed as a one-way ANOVA. Simple-effect means were separated by LSD when a significant treatment effect was observed.

In Trial 2, digestion data were analyzed testing the main effect of processing or grain type using SAS (1989) procedures appropriate for a $4 \times 4$ Latin square design; animal, period, and treatment were included in the model. In situ disappearance and $\mathrm{pH}$ data were analyzed using a model appropriate for a 4 $\times 4$ Latin square with a split plot in time. Effects included in the model were animal, treatment, period, hour, treatment $\times$ hour, and period $\times$ treatment $\times$ animal; period $\times$ treatment $\times$ hour was used as the error term to test treatment effects. When hour $x$ treatment interactions were significant, the data were sorted and analyzed by hour. When a grain type $x$ processing method interaction was observed, data were analyzed as a one-way ANOVA. Means were separated by LSD when a significant treatment effect was observed.

\section{Results and Discussion}

Trial 1. Steer initial BW was not different $(P=$ .758) across treatments (Table 3). A grain type $\times$ processing method interaction was observed ( $P<$ .075) for final weight, weight gain, ADG, and carcass weight; therefore, these data were analyzed for simple treatment effects. Final unshrunk BW was higher for cattle fed dry-rolled grains than for cattle fed extruded grains $(P=.003)$. There was no difference $(P>.1)$ in final weight between cattle fed dry-rolled corn and those fed dry-rolled grain sorghum; however, cattle fed dry-rolled grain sorghum were $27 \mathrm{~kg}$ lighter. This difference in final weight apparently caused the interaction that was present for the main effects for final weight. Final BW was estimated by dividing hot carcass weight by an average dressing percentage of 
Table 3. Simple effects of processing corn or grain sorghum on feedlot performance by steers fed $110 \mathrm{~d}$

\begin{tabular}{|c|c|c|c|c|c|c|c|}
\hline \multirow[b]{2}{*}{ Item, kg } & \multicolumn{2}{|c|}{ Corn } & \multicolumn{2}{|c|}{ Grain sorghum } & \multirow[b]{2}{*}{ SE } & \multicolumn{2}{|c|}{ P-value } \\
\hline & Rolled & Extruded & Rolled & Extruded & & One-way ${ }^{a}$ & Interaction ${ }^{\mathrm{b}}$ \\
\hline Initial BW & 420 & 405 & 412 & 418 & 11 & .758 & .347 \\
\hline Final BW & $597^{c}$ & $524^{d}$ & $570^{c}$ & $541^{d}$ & 11 & .003 & .074 \\
\hline Weight gain & $176^{c}$ & $118^{\mathrm{e}}$ & $157^{d}$ & $122^{\mathrm{e}}$ & 5 & .001 & .047 \\
\hline ADG & $1.61^{\mathrm{C}}$ & $1.08^{\mathrm{e}}$ & $1.44^{d}$ & $1.11^{\mathrm{e}}$ & .1 & .001 & .049 \\
\hline Carcass weight & $365^{c}$ & $312^{\mathrm{e}}$ & $345^{d}$ & $319^{e}$ & 7 & .001 & .073 \\
\hline
\end{tabular}

aOne-way $\mathrm{P}$-value is from one-way ANOVA.

bInteraction P-value is from $2 \times 2$ factorial ANOVA.

$c, d, e$ Row means with different superscripts differ $(P<.1)$.

62 (data not shown). This method of calculating live weight did not change the results of performance data compared with using actual live weight.

Steers fed dry-rolled corn had higher $(P=.001)$ ADG and carcass weights than steers fed either dryrolled grain sorghum or extruded grains; increased gains were 12 and $46 \%$ higher per day than they were for steers fed dry-rolled grain sorghum and the extruded diets. Steers fed dry-rolled grain sorghum gained more weight and had heavier carcasses than steers fed extruded grains. There was no difference between steers fed extruded grains in weight gain, ADG, or carcass weight $(P>.1)$.

Performance of steers that were fed the dry-rolled corn diet or dry-rolled grain sorghum diet was superior to that of steers fed extruded forms of these grains. Results from this trial indicate a much larger decrease in performance owing to feeding extruded grains than those observed by Matsushima et al. (1969), who reported that cattle fed either extruded corn or grain sorghum at $57 \%$ of the diet gained $5 \%$ slower and had an $8 \%$ lower feed conversion than cattle fed either high-moisture or flaked corn at a 57\% level of the diet. In a later study, Matsushima (1970) observed that cattle fed diets containing $68 \%$ grain extruded corn had gains similar to cattle fed whole corn, and both were higher than the level of gain supported by flaked corn; however, McLaren and Matsushima (1971) reported reduced performance in cattle as percentage of extruded grain in a finishing diet was increased from 62 to $74 \%$ and decreased gains as percentage roughage in the diets decreased. In the current study, grain was fed at $78.6 \%$ of the diet, which is higher than in previous trials. In addition, the primary source of roughage in the current trial was dehydrated alfalfa pellets, which may have resulted in less-effective fiber than the roughage used in previous trials. In the current trial, cattle were on the step-up diets for the first $26 \mathrm{~d}$. During this time, the level of grain in the diet was less than $70 \%$. There was no difference in ADG during the first $28 \mathrm{~d}$ of the trial (data not shown).

There were no $(P>.1)$ processing $\times$ grain type interactions for dry matter intake, feed efficiency, or carcass data. Steers fed extruded diets consumed 31\% less feed $(P=.001)$ than steers fed dry-rolled diets; however, there was no difference $(P=.118)$ in feed efficiency between the two processing methods. Feed efficiencies between the two treatments were probably similar because steers fed extruded grains consumed less feed and gained less than steers fed dry-rolled grains. Dry matter intake was higher $(P=.028)$ for steers fed grain sorghum diets than for steers fed corn diets. Due to the lower intake and higher gains of steers fed corn diets, the feed efficiency of steers fed corn diets was improved ( $P=.006$ ) compared with that of steers fed grain sorghum diets.

Steers fed extruded grains had lower $(P=.016)$ dressing percentages, lower quality grade $(P=.085)$, and smaller longissimus muscles $(P=.001)$ and tended to have lower marbling scores $(P=.113)$ and fat thickness ( $P=.178$ ) than steers fed dry-rolled grain (Table 4). Seventy-seven percent of the steers fed either dry-rolled corn or grain sorghum graded Choice, but only $42 \%$ of steers consuming extruded corn or sorghum graded Choice (data not shown). The results are likely due to the lower gains of cattle fed extruded grains during the trial and lower carcass weights of cattle at slaughter. Yield grade of steers was not affected ( $P=.886)$ by grain processing; however, the method used to calculate yield grade assumed a constant for internal fat. Grain source did not affect $(P>.208)$ carcass data of steers.

Trial 2. There was no processing method $\times$ grain source interaction $(P>.119)$ on digestion or intake values. Apparent DM and starch digestibilities were higher $(P<.074)$ for steers fed extruded grains than for those fed dry-rolled grain (Table 5). Dry matter digestion was increased by 5 units, and starch digestion was increased by 10 units as a result of extruding of grains. The increase in digestibility may be due in part to the lower intakes of steers fed extruded grains. Schneider and Flatt (1975) summarized the literature and indicated that increased levels of feed intake are generally associated with a depression in digestibility. Digestibilities of NDF and ADF were lower $(P<.032)$ with steers fed extruded grains. Digestion of NDF was decreased by $23 \%$, and ADF 
Table 4. Effect of grain source and processing method on intake, conversion, and carcass data of feedlot steers

\begin{tabular}{|c|c|c|c|c|c|c|c|}
\hline \multirow[b]{2}{*}{ Item } & \multicolumn{3}{|c|}{ Processing method } & \multicolumn{3}{|c|}{ Grain source } & \multirow[b]{2}{*}{ SE } \\
\hline & Dry-rolled & Extruded & P-value & Corn & Grain sorghum & P-value & \\
\hline DMI, kg & 10.6 & 7.3 & .001 & 8.6 & 9.2 & .028 & .2 \\
\hline Feed efficiency ${ }^{a}$ & 143 & 150 & .118 & 154 & 139 & .006 & 3 \\
\hline Dressing percentage & 60.8 & 59.2 & .016 & 60.4 & 59.6 & .242 & .4 \\
\hline Marbling score ${ }^{b}$ & 44.8 & 39.9 & .113 & 41.8 & 42.9 & .720 & 2.0 \\
\hline Quality grade ${ }^{c}$ & 6.8 & 5.9 & .085 & 6.2 & 6.5 & .488 & .3 \\
\hline Fat thickness, cm & 1.0 & .8 & .178 & .8 & 1.0 & .242 & .1 \\
\hline Longissimus muscle & 885 & 775 & O०१ & 844 & 816 & 208 & 15 \\
\hline Yield grade & $\begin{array}{r}0.5 \\
2.6\end{array}$ & 2.6 & .886 & $\begin{array}{r}8.4 \\
2.5\end{array}$ & $\begin{array}{r}0.0 \\
2.7\end{array}$ & .277 & $\begin{array}{r}1.5 \\
.1\end{array}$ \\
\hline
\end{tabular}

${ }^{\mathrm{a}} \mathrm{Grams}$ of weight gain per kilogram of feed.

bSlight $=30$; small $=40$; modest $=50$; moderate $=60$.

'Select $^{+}=6$; Choice $^{-}=7$; Choice $^{0}=8$.

digestion decreased $30 \%$. There was no difference ( $\mathrm{P}=$ .270) in digestible energy of diets as a result of processing method. Type of grain had no effect on DM, starch, NDF or ADF digestibility, or DE values ( $P>$ .160) of ruminally cannulated steers fed extruded or dry-rolled diets.

Dry matter intake, digestible DMI, and DE intake per unit of body weight were lower $(P=.001)$ for steers fed extruded grains than for steers fed dryrolled grains (Table 5). Steers fed extruded grains consumed $36 \%$ less DM, 31\% less digestible DM, and $32 \%$ less DE on a body weight basis than steers fed the dry-rolled grains.

A processing method $\times$ grain type interaction $(P<$ .05) was present at all times except at 2, 4, and $6 \mathrm{~h}$ of incubation for DM disappearance data; therefore, data are presented for simple treatment effects (F igure 1 ). Both extruded grains disappeared more rapidly ( $P<$ .021) from Dacron bags at all incubation times than did dry-rolled grains. There was no difference in DM disappearance between extruded corn and extruded grain sorghum. There was no difference $(P>.05)$ in DM disappearance between extruded grains after $\mathrm{h} 8$.
The majority of the DM had disappeared from the bags containing extruded corn $(80.1 \%)$ and extruded grain sorghum (75.3\%) by $\mathrm{h} 8$. In contrast, only 19.6 and $24.4 \%$ of the DM had disappeared from the bags containing dry-rolled corn and dry-rolled grain sorghum, respectively. Dry-rolled grain sorghum had a higher percentage $(P<.05)$ of disappearance from Dacron bags at all times than did dry-rolled corn.

There was no processing method $\times$ grain interaction $(P>.1)$ for starch disappearance from Dacron bags. Starch disappearance from bags containing extruded grains was higher $(P<.008)$ at all incubation times than that from bags containing dry-rolled grains (Figure 2). By h 12, 89\% of the starch in extruded grains had disappeared, but only $27 \%$ of the starch in dry-rolled grains had disappeared. These data may be misleading because the dry-rolled grain was not finely ground before it was placed in the Dacron bags and grain did not have the grinding associated with eating. The data do indicate a large improvement in starch digestion in the rumen. Galyean et al. (1981) reported that steam-flaking corn increased starch utilization in situ compared with that of dry-ground

Table 5. Effect of grain source and processing method on digestibility and digestible energy of feedlot diets by steers

\begin{tabular}{|c|c|c|c|c|c|c|c|}
\hline \multirow[b]{2}{*}{ Item } & \multicolumn{3}{|c|}{ Processing method } & \multicolumn{3}{|c|}{ Grain source } & \multirow[b]{2}{*}{ SE } \\
\hline & $\begin{array}{l}\text { Dry- } \\
\text { rolled }\end{array}$ & Extruded & P-value & Corn & Grain sorghum & P-value & \\
\hline \multicolumn{8}{|l|}{ Digestibility } \\
\hline DM & 72.7 & 77.1 & .074 & 76.7 & 73.1 & .160 & 1.9 \\
\hline Starch & 85.5 & 96.4 & .001 & 92.0 & 89.9 & .293 & 1.6 \\
\hline NDF & 58.2 & 44.9 & .031 & 48.8 & 54.3 & .307 & 4.0 \\
\hline ADF & 48.7 & 34.1 & .005 & 39.0 & 43.8 & .238 & 2.9 \\
\hline $\mathrm{DE}, \mathrm{mcal} / \mathrm{kg}$ & 2.9 & 3.0 & .270 & 3.0 & 3.0 & .801 & .1 \\
\hline \multicolumn{8}{|l|}{ Intake } \\
\hline $\mathrm{DM}, \mathrm{g} / \mathrm{kg} \mathrm{BW}$ & 20.5 & 13.2 & .001 & 16.4 & 17.3 & .365 & .9 \\
\hline Digestible DM, g/kg BW & 14.7 & 10.1 & .001 & 12.4 & 12.4 & .816 & .7 \\
\hline $\mathrm{DE}, \mathrm{kcal} / \mathrm{kg} \mathrm{BW}$ & 59.7 & 40.3 & .001 & 48.9 & 51.1 & .489 & 3.0 \\
\hline
\end{tabular}




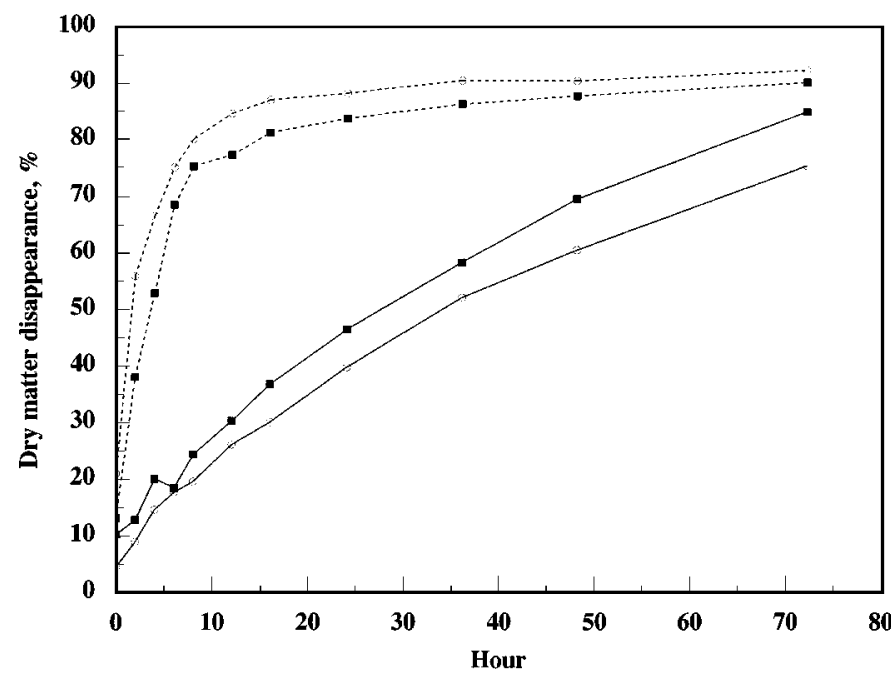

Figure 1. Dry matter disappearance of dry-rolled corn (一o-), dry-rolled grain sorghum (-—), extruded corn (---0---), and extruded grain sorghum (------) from Dacron ${ }^{\circledR}$ bags incubated in the rumen of steers fed the respective diets.

corn. Grain type only had an effect $(P<.05)$ on starch disappearance from Dacron bags at $\mathrm{h} 12,16,48$, and 72 (data not shown).

There were no processing method $\times$ grain type interactions $(\mathrm{P}=.1$ ) on ruminal $\mathrm{pH}$ data. Ruminal $\mathrm{pH}$ levels were similar $(P>.233$ ) between corn- and grain sorghum-fed steers at all time periods (data not shown). Ruminal pH levels were lower $(P<.052)$ in steers fed extruded grain than in those fed dry-rolled grain (Figure 3 ) at all time periods except at $1 \mathrm{~h}$ before feeding ( $P>$.349). Ruminal fluid from steers fed extruded grains had $\mathrm{pH}$ levels of 5 or below beginning at $5 \mathrm{~h}$ after feeding, and the levels did not increase above 5.1 until $17 \mathrm{~h}$ after feeding.

Cattle that consumed extruded grains had lower intakes in both trials. However, the DM and starch digestibility of the extruded grains were higher than those of the dry-rolled grains. Total tract starch digestibility was $96.4 \%$ for steers fed extruded grain vs $85.5 \%$ for steers fed dry-rolled grain diets. The increase in starch digestibility is in agreement with Theurer (1986), who reported that heat and moisture processing of grains increase total starch digestibility. Not only were the dry matter and starch in the extruded grains digested at a higher level, but the disappearance of the DM and starch from the Dacron bags indicates a very rapid rate of digestion. Starch fermentation in the rumen seems to have occurred much more rapidly and to a greater extent in cattle fed extruded grain than in cattle fed dry-rolled grain. This would leave very little starch to be digested in the lower tract of cattle that consume extruded grain.

Digestible energy intake of performance cattle in

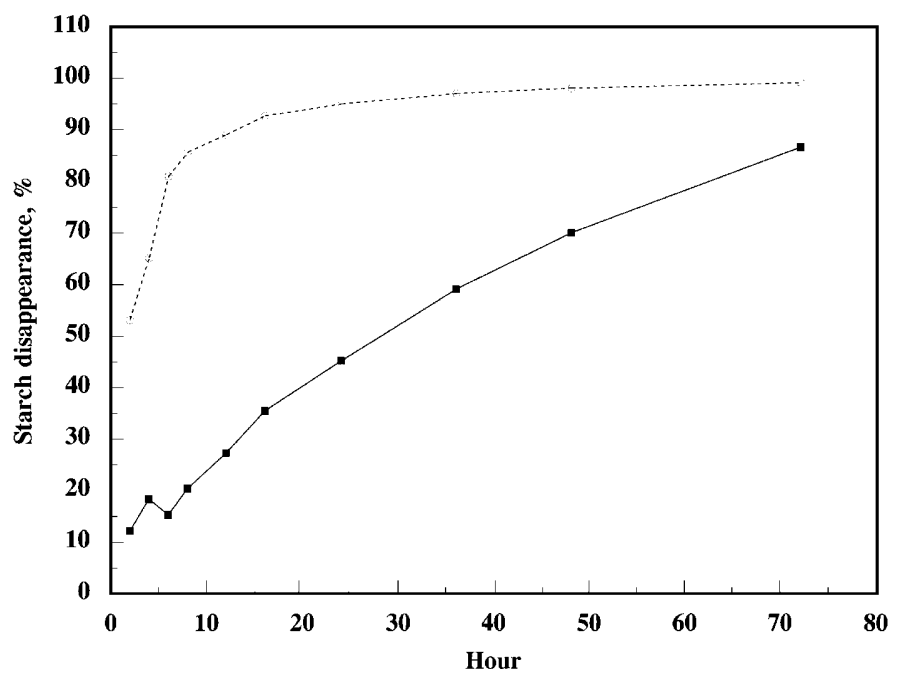

Figure 2. Starch disappearance of extruded ( $\bullet-)$ and dry-rolled (- -) grains from Dacron ${ }^{\circledR}$ bags incubated in the rumen of steers fed either dry-rolled or extruded corn or dry-rolled or extruded grain sorghum.

Trial 1 can be calculated from diet DE values derived in Trial 2. Calculated DE intake values are 31.1, 20.3, 30.8 , and $24.4 \mathrm{Mcal} / \mathrm{d}$ for steers fed dry-rolled corn, extruded corn, dry-rolled sorghum, and extruded sorghum, respectively. The ranking of these values coincides with ADG of steers in these same treatments.

The NDF and ADF digestibilities were $23 \%$ and $30 \%$ higher, respectively, for cattle fed dry-rolled grain than for those fed extruded grain. Lower fiber digestibility in steers fed extruded grain than in steers fed dry-rolled grain contradicts DM and starch digesti-

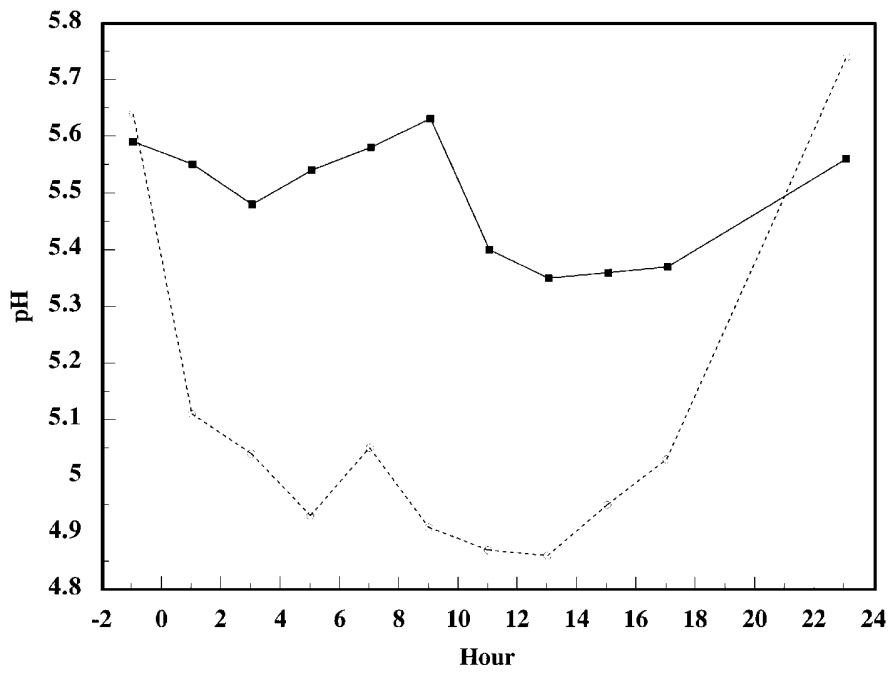

Figure 3. Ruminal $\mathrm{pH}$ from steers fed either extruded (- - ) and dry-rolled (- - ) grains. Samples were taken at $-1 \mathrm{~h}$ and at $1,3,5,7,9,11,13,15,17$, and $23 \mathrm{~h}$ after feeding. 
bility, which was higher in steers that consumed extruded grain. This may be due to the lower ruminal $\mathrm{pH}$ levels in steers fed extruded grain. At lower $\mathrm{pH}$, cellulolytic (fiber-digesting) bacteria become less active and thus hamper cellulose digestion (Church, 1988). The ruminal $\mathrm{pH}$ of steers fed extruded grains was below 5 for a considerable portion of the 24-h period.

In a review of the influence of processing methods on performance and feed conversion by beef cattle, Hale (1980) reported that steam-flaking, reconstituting, and micronizing of corn and grain sorghum decreased the amount of feed needed for a kilogram of gain; however, daily gain was not increased. This is in contrast to the lower gains and feed efficiency of cattle fed extruded grains in the current study. Ørskov (1976) suggested that processing of cereal grains should be to the extent that is sufficient to avoid large reductions in digestibility, but that further processing to increase the extent and rate of ruminal fermentation could be undesirable. This may partially explain the effects observed in this trial. The rapid fermentation of extruded grains and the use of dehydrated alfalfa pellets as a roughage source in this study resulted in low ruminal $\mathrm{pH}$, which probably caused subclinical acidosis in some of the cattle. This would explain the greatly reduced feed intake observed with the cannulated cattle in Trial 2 and the finishing cattle in Trial 1. The lower rates of gain in cattle that consumed extruded grain than in cattle fed dry-rolled grain was due to lower intakes, but they may also have been partially due to subdinical acidosis. Cattle fed extruded diets may have suffered less from acidosis during the step-up period, when the level of extruded grains in the diet was lower and the roughage content of the diet was higher. This would explain the similar dry matter intakes and performance during the first $28 \mathrm{~d}$.

\section{Implications}

This research suggests that feeding extruded corn or grain sorghum to finishing cattle at levels of $78.6 \%$ of the diet decreases performance of cattle. Starch from extruded corn and sorghum was fermented at a very rapid rate in the rumen, which led to low ruminal $\mathrm{pH}$ levels. The extended period in which cattle had ruminal $\mathrm{pH}<5$ probably resulted in subclinical acidosis and may have reduced feed intake. The slight increase in dry matter digestibility of the extruded grains vs dry-rolled grains may be due to lower intakes of a more fermentable substrate. This increase did not outweigh the large reduction in feed intake and the possible increase in subclinical acidosis as evidenced by the slower rates of gain in the steers that consumed extruded corn or sorghum. Data from these trials indicate that both extruded corn and grain sorghum are highly fermentable products and probably should not be used as the sole grain source; they may offer some benefit if fed at a lower level with other sources of grain.

\section{Literature Cited}

AOAC. 1980. Official Methods of Analysis (12th E d.) Association of Official Analytical Chemists, Washington, DC.

Church, D. C. 1988. The Ruminant Animal: Digestive Physiology and Nutrition. Prentice-Hall, Englewood Cliffs, NJ .

Ellis, G. F., J r., and J. A. Carpenter, J r. 1966. Popped milo in fattening rations for beef cattle. J . Anim. Sci. 25:594 (Abstr.).

Galyean, M. L., D. G. Wagner, and F. N. Owens. 1981. Dry matter and starch disappearance of corn and sorghum as influenced by particle size and processing. J. Dairy Sci. 64:1804-1809.

Goering, H. K., and P. J. Van Soest. 1970. Forage fiber analysis (apparatus, reagents, procedures, and some application). Agric. Handbook No. 379. ARS, USDA, Washington, DC.

Guyer, P. Q. 1976. Grain processing for feedlot cattle. Univ. of Neb., Cooperative Ext. Serv. NebGuide. G73-14:1-5.

Hale, W. H. 1973. Influence of processing on the utilization of grains (starch) by ruminants. J. Anim. Sci. 37:1075-1080.

Hale, W. H. 1980. Feed preparation and processing. In: D. C. Church (E d.) Digestion Physiology and Nutrition of Ruminants. Vol. 3 (1st Ed.). pp 49-76. O \& B Books, Corvallis, OR.

Harper, J. M. 1981. Extrusion of Foods. Vol. II. pp 41-59. CRC Press, Boca Raton, FL.

Huntington, G. B. 1997. Starch utilization by ruminants: From basics to the bunk. J. Anim. Sci. 75:852-867.

J ohnson, D. E., J . K. Matsushima, and K. L. Knox. 1968. Utilization of flaked vs. cracked corn by steers with observations on starch modification. J. Anim. Sci. 27:1431-1437.

Matejovsky, K. M., and D. W. Sanson. 1995. Intake and digestion of low-, medium-, and high-quality grass hays by lambs receiving increasing levels of corn supplementation. J. Anim. Sci. 73: 2156-2163.

Matsushima, J. K. 1970. Feed processing for feedlot cattle. Anim. Nutr. Health. (May 1970):8-10.

Matsushima, J. K., R. J. MCLaren, C. P. McCann, and G. E. Kellog. 1969. Processing grains for feedlot cattle. Colo. State Univ. Beef Nutr. Res. Rep., Fort Collins.

McLaren, R. J ., and J. K. Matsushima. 1971. Extruded corn compared with flaked and whole corn in finishing rations. Colo. State Univ. Beef Nutr. Res. Bull. 918:14-15.

McRae, J. C., and D. C. Armstrong. 1968. Enzyme method for determination of $\alpha$-linked polymers in biological materials. J . Food Sci. Agric. 19:578-581.

McQueen, R. E., and J.W.G. Nicholson. 1979. Modification of neutral-detergent fiber procedure for cereals and vegetables using $\alpha$-amylase. J . Assoc. Off. Anal. Chem. 62:676-680.

Ørskov, E. R. 1976. The effect of processing on digestion and utilization of cereals by ruminants. Proc. Nutr. Soc. 35:245-257.

Rooney, L. W., and R. L. Pflugfelder. 1986. Factors affecting starch digestibility with special emphasis on sorghum and corn. J. Anim. Sci. 63:1607-1623.

SAS. 1989. SAS/STAT ${ }^{\circledR}$ User's Guide (Version 6, 4th E d.) SAS Inst. Inc., Cary, NC.

Schneider, B. H., and W. P. Flatt. 1975. The Evaluation of Feeds Through Digestibility Experiments. The University of Georgia Press, Athens.

Theurer, C. B. 1986. Grain processing effects on starch utilization by ruminants. J. Anim. Sci. 63:1649-1662.

Theurer, C. B., J. T. Huber, and A. Delgado-Elorduy. 1996. Steamflaking improves starch utilization and milk production parameters. In: Proc. Cornell Nutr. Conf., Dept. Anim. Sci., Cornell Univ., Ithaca, NY. pp 121-130.

Walhain, P., M. Foucart, and A. Thewis. 1992. Influence of extrusion on ruminal and intestinal disappearance in sacco of pea ( $\mathrm{Pisum}$ savitum) proteins and starch. Anim. Feed Sci. Technol. 38: 43-55. 